\title{
The Effect of Transformational Leadership and Organizational Culture on Teacher Satisfaction and Performance of SMP Negeri 1 Pulau Rakyat Asahan
}

\author{
Rosma Nababan ${ }^{1}$, Lukman Pardede ${ }^{2}$ and Sri Murni Sinaga ${ }^{1}$ \\ 1.Darma Agung University Medan, Indonesia \\ 2.HKBP Nommensen University Medan, Indonesia
}

\begin{abstract}
Transformational leadership and organizational culture on teacher satisfaction and performance at SMP Negeri 1 Pulau Rakyat Asahan really need to be done by a leader in an institution or organization. Research on transformational leadership and organizational culture on teacher satisfaction and performance at SMP Negeri 1 Pulau Rakyat Asahan has been carried out. This research is an empirical study at SMP Negeri 1 Pulau Rakyat Asahan. The purpose of this study was to examine the effect of transformational leadership and organizational culture on teacher satisfaction and performance at SMP Negeri 1 Pulau Rakyat Asahan. From the research results, the role of transformational leadership and organizational culture becomes very important in the success of an organization for the satisfaction and performance of its subordinates. This research is a descriptive study with a sample of 30 teachers of SMP Negeri 1 Pulau Rakyat Asahan. The technique used in the implementation of this research is to provide questionnaires to all respondents to be filled out and collected. From the results of tabulation of research data on Job Satisfaction indicators obtained by $80.00 \%$ and on Performance indicators obtained by $86.67 \%$. From the results of this study, it was concluded that transformational leadership and organizational culture on job satisfaction and teacher performance at SMP Negeri 1 Pulau Rakyat Asahan were very good.
\end{abstract}

Keywords:transformational leadership and organizational culture, satisfaction and performance.

DOI: $10.7176 / \mathrm{JEP} / 13-4-05$

Publication date: February $28^{\text {th }} 2022$

\section{Introduction}

Leadership is an aspirational power, a spirit power, and creative moral force, which is able to influence members to change attitudes, so that they are in line with the wishes and aspirations of the leader. Leadership is a pattern and method applied by a leader in guiding and directing his subordinates. Organizations need reformist leaders who are capable of being the driving force of organizational change. Leadership is the process of encouraging and helping others to work enthusiastically to achieve goals (Mintzberg in Davis, 1996). In organizational life, leaders have a very important role. All activities, starting from planning, implementing supervision to determining goals, are determined by the leadership. The progress of organizational life depends on the leader's ability to control people, equipment, resources and other resources.

Transformational leadership and organizational culture include developing closer relationships between leaders and followers. Transformational leadership in principle is to do better than what is usually done, in other words it can increase the confidence or self-confidence of subordinates which will affect satisfaction and performance.

Leaders play a very important role in social and state life in groups or organizations. Leadership is the opening for the success of the organization (Kartono, 1998). In any field and in any country a leader is needed because his function is to lead, but all of this is adjusted to the characteristics of the group and its subordinates, and besides that it is very dependent on the times. A strong leader and capable of high loyalty and dedication will greatly affect the progress and development and survival of the organization. For this reason, transformational leadership is needed from a leader so that each of his subordinates can work calmly and in high spirits. In largescale organizations, leaders are seen as a very decisive element in the process of developing the business world (Lok and Crawford, 2004).

The quality of the leader is often considered as the most important factor in the success or failure of the organization (Menon, 2002), as well as the success or failure of an organization, both business and public oriented, usually perceived as the success or failure of the leader. So important is the role of the leader that the issue of leadership has become a focus that has attracted the attention of researchers in the field of organizational behavior. According to Scarnati (2002), the leader has a very big influence on the success of the organization. Leaders play a key role in formulating and implementing organizational strategies. Commitment in the organization will make employees give their best to the organization where they work. It is even mentioned that leaders who have a high commitment to the organization will tend to be happy to help, to be able to work together (Muh Su'ud, 2000). Conformity between leadership, norms and organizational culture is seen as a key 
prerequisite for the successful achievement of organizational goals (Yulk, 1989). Although in relation to leadership theory in North America is limited from other countries (Lapin, 1990).

Job satisfaction and performance is a theory or practical concept that is very important, because it is the impact or result of the effectiveness of performance and success in work. Job satisfaction and low performance in the organization are a series of decreased task performance, increased absenteeism, and decreased organizational morale. While at the individual level, job satisfaction and performance are associated with a great desire to leave work. Transformational leadership refers to the leader's work performance measured based on the standards or criteria that have been set by the Institute. Management to achieve very high leadership performance, especially to improve the overall performance of the Institution. Factors that influence transformational leaders include organizational strategy (value of short-term and long-term goals, organizational culture and economic conditions) and individual attributes such as abilities and skills. The transformational leadership of the leader can increase the job satisfaction and performance of his subordinates in the organization. According to Fuad Mas'ud (2004), the progress and success of the organization is highly dependent on the leader. The extent to which the leader is able and willing to work hard, creative, innovative, loyal, disciplined, honest and responsible will determine organizational achievement. Therefore, to find out how far the leader works, the leader needs to evaluate its performance. Leaders must have leadership skills. Without the ability, people will not want to listen to it. Because leaders must be able to arouse the respect of others.

There are several types of differences in transformational leadership and ways of working among the various individuals and departments within the organization that complicate the task of coordinating the parts of the organization effectively, namely: a) Differences in orientation towards specific goals. Members of different departments develop their own views on how to achieve the good interests of the organization; b) Differences in time orientation. Leaders will pay more attention to problems that must be solved immediately in a short period of time. The research and development department is more involved with long-term issues; c) Differences in interpersonal orientation. Transformational leadership activities require fast communication and decision-making so that the process runs smoothly, while the research and development department may be more relaxed and everyone can express opinions and discuss with one another; and d). Differences in the formality of the structure. Each type of unit in the organization has different methods and standards for evaluating programs against objectives and for remuneration for subordinates. The success or failure of an organization is usually perceived as the success or failure of the leader.

According to Kohl, et all., (1995), leaders have a very large influence on organizational success. Leaders play a key role in formulating and implementing organizational strategies.

\section{Research Methods}

In this paper, the method used is through primary data. Primary data was obtained by distributing questionnaires addressed and filled out by teachers at SMP Negeri 1 Pulau Rakyat Asahan. The number of samples of teachers in SMP Negeri 1 Pulau Rakyat Asahan is 30 people.

\section{Results and Discussion}

Based on the results of research and data processing that has been carried out on the influence of transformational leadership and organizational culture on job satisfaction and performance at SMP Negeri 1 Pulau Rakyat Asahan teachers, it can be discussed as follows:

\section{Job satisfaction}

Based on the results of research and tabulation of data that has been carried out on job satisfaction indicators, it can be seen in Table 1 below.

Table 1. Tabulation of the number of responses in filling out the questionnaire on indicators of job satisfaction

\begin{tabular}{|c|l|c|}
\hline No & Indicator of job satisfaction & Total (People) \\
\hline 1 & Loyalty & 25 \\
\hline 2 & Responsible & 24 \\
\hline 3 & Cooperation & 24 \\
\hline 4 & Honesty & 25 \\
\hline 5 & Accuracy & 25 \\
\hline \multicolumn{2}{r|}{ Total } & $\mathbf{1 2 3}$ \\
\hline \multicolumn{2}{r|}{ Average } & $\mathbf{2 4 , 6 0}$ \\
\hline
\end{tabular}

From Table 1 above the indicators of job satisfaction for respondents as many as 30 people, obtained answers to Loyalty as many as 25 people, who answered Responsibilities as many as 24 people, who answered the cooperation as many as 24 people, and who answered Honesty as many as 25 people and accuracy of 25 
people. From the overall results, it was obtained as many as 25 people, meaning that there were 5 people who did not give a response. Therefore, from the results obtained, it can be said that the transformational leadership style towards indicators of job satisfaction can be said to be good.

Based on the results of the research and data tabulations that have been made on the indicators of job satisfaction, the percentage of respondents can be seen in Table 2 below.

Table 2. The percentage of the number of responses in filling out the questionnaire on indicators of job satisfaction

\begin{tabular}{|c|l|c|}
\hline No & Indicator of job satisfaction & Percentage (\%) \\
\hline 1 & Loyalty & 83,33 \\
\hline 2 & Responsible & 80,00 \\
\hline 3 & Cooperation & 80,00 \\
\hline 4 & Honesty & 83,33 \\
\hline 5 & Accuracy & 83,33 \\
\hline & & $\mathbf{4 1 0 . 0 0}$ \\
\hline & Total & $\mathbf{8 2 , 0 0}$ \\
\hline
\end{tabular}

From Table 2 above, the job satisfaction indicators for respondents are 30 people, the percentage who answered Loyalty was $83.33 \%$, those who answered Responsibility was $80.00 \%$, Cooperation was $80.00 \%$, Honesty was $83.33 \%$ and Accuracy by $83.33 \%$. From the results of the overall average percentage obtained by $82.00 \%$, meaning that only $18.00 \%$ did not provide a response.

This implies that job satisfaction can be increased if transformational leadership and organizational culture are continuously improved. Transformational leadership and organizational culture are variables that have an influence in relation to job satisfaction. This shows that transformational leadership and organizational culture greatly affect job satisfaction. The results of data tabulation and data processing in this study strengthen the results of empirical research from Griffin (1980) and Mc Cue, Clifford, et all., 1997) which states that there is a correlation between transformational leadership and organizational culture with job satisfaction. Therefore, from the results obtained, it can be said that the transformational leadership style and organizational culture on job satisfaction indicators can be said to be good.

For more details, this can be seen in Figure 1 below.

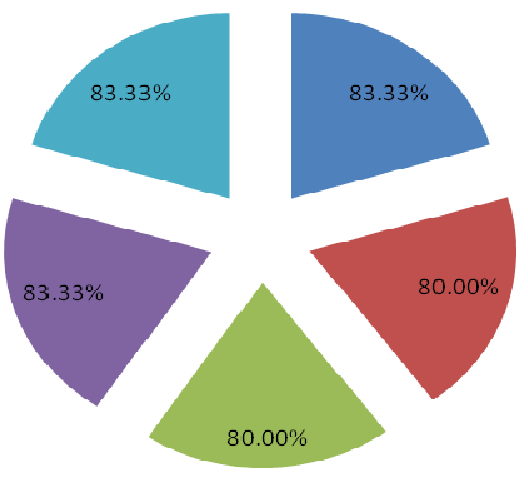

Fig. 1. Transformational leadership and organizational culture through job satisfaction indicators

From Fig. 1. above, the percentages are: Loyalty is $83.33 \%$, Responsibility is $80.00 \%$, Cooperation is $80.00 \%$, Honesty is $83.33 \%$ and Accuracy is $83.33 \%$. Therefore, from the results obtained, it can be said that the influence of transformational leadership style and organizational culture on job satisfaction indicators can be said to be good.

\section{Performance}

Based on the results of research and tabulation of data that has been carried out on performance indicators, it can be seen in Table 3 below.

Table 3. Tabulation of the number of responses in filling out the questionnaire on performance indicators

\begin{tabular}{|c|l|c|}
\hline No & \multicolumn{1}{|c|}{ Performance Indicator } & Total (people) \\
\hline 1 & Punctuality & 26 \\
\hline 2 & Use office equipment properly & 25 \\
\hline 3 & Obedience & 27 \\
\hline \multicolumn{2}{r|}{ Total } & $\mathbf{7 8}$ \\
\hline \multicolumn{2}{r}{ Average } & $\mathbf{2 6}$ \\
\hline
\end{tabular}


From Table 3 above, the performance indicators for respondents were 30 people, it was obtained that 26 people answered Punctuality, 25 people answered Using office equipment well, and 27 people answered Obedience. From the overall results obtained an average of 26 people, meaning that only 4 people did not give a response. Therefore, from the results obtained, it can be said that the influence of transformational leadership style and organizational culture on performance indicators can be said to be good.

Based on the results of research and tabulation of data that has been carried out on performance indicators, the percentage of respondents can be seen in Table 4 below.

Table 4. Percentage of the number of responses in filling out the questionnaire on performance indicators

\begin{tabular}{|c|l|c|}
\hline No & \multicolumn{1}{|c|}{ Performance Indicator } & Percentage (\%) \\
\hline 1 & Punctuality & 26 \\
\hline 2 & Use office equipment properly & 25 \\
\hline 3 & Obedience & 27 \\
\hline \multicolumn{2}{|r|}{ Total } & $\mathbf{7 8}$ \\
\hline \multicolumn{2}{|r|}{ Average } & $\mathbf{2 6}$ \\
\hline
\end{tabular}

From Table 4 above on the performance indicators of 30 respondents, the percentage who answered Punctuality was $86.67 \%$, those who answered Using office equipment well were $83.33 \%$, and those who answered Obedience were $90.00 \%$. From the overall results obtained an average percentage of $86.67 \%$, meaning that only $13.33 \%$ did not provide a response.

This implies that performance can be improved if transformational leadership and organizational culture are continuously improved. Transformational leadership and organizational culture are variables that have an influence in relation to performance. Therefore, from the results obtained, it can be said that the influence of transformational leadership and organizational culture on performance indicators can be said to be good.

For more details, this can be seen in Figure 2 below.

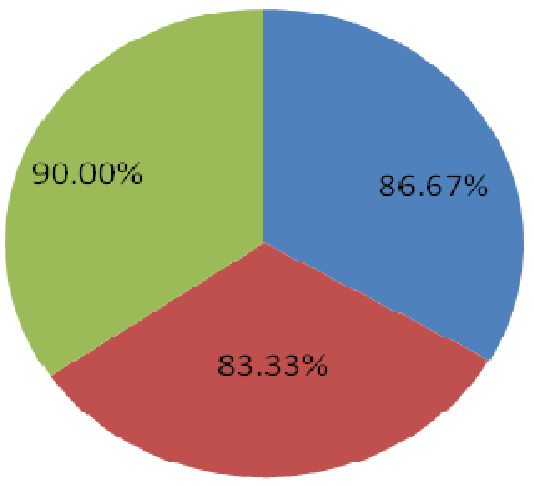

Fig. 2.Transformational leadership and organizational culture through performance indicators

From Fig. 2. above, the percentage of Punctuality is $86.67 \%$, those who answer Using office equipment well are $83.33 \%$, and those who answer Obedience are $90.00 \%$. Therefore, from the results obtained, it can be said that the transformational leadership style and organizational culture on performance indicators can be said to be good.

Of all the indicators carried out, the overall indicators that have been carried out can be seen in Table 5 below.

Table 5. Tabulation of the number of responses in filling out the questionnaire on all indicators

\begin{tabular}{|c|l|c|}
\hline No & \multicolumn{1}{|c|}{ Indicator } & Total (people) \\
\hline 1 & Job satisfaction & 24 \\
\hline 2 & Performance & 26 \\
\hline \multicolumn{2}{|r|}{ Total } & $\mathbf{5 0}$ \\
\hline \multicolumn{2}{|c|}{ Average } & $\mathbf{2 5}$ \\
\hline
\end{tabular}

From Table 5 on the overall indicators that have been carried out on 30 respondents, it was obtained that 24 people answered on the Job Satisfaction indicator and 26 people on the performance indicator. Based on the results of research and tabulation of data that has been carried out on job satisfaction and performance indicators, the percentage of respondents can be seen in Table 6 below. 
Table 6. Percentage of the number of responses in filling out the questionnaire on all indicators

\begin{tabular}{|c|l|c|}
\hline No & Indicator & Percentage (\%) \\
\hline 1 & Job satisfaction & 80,00 \\
\hline 2 & Performance & 86,67 \\
\hline \multicolumn{2}{r|}{ Total } & $\mathbf{1 6 6 , 6 7}$ \\
\hline \multicolumn{2}{r|}{ Average } & $\mathbf{8 3 , 3 3}$ \\
\hline
\end{tabular}

From Table 6 on the overall indicators that have been carried out on 30 respondents, it is obtained that the percentage who answered the Job Satisfaction indicator was $80.00 \%$ and Performance was $86.67 \%$.

Overall, these indicators can be seen in Fig. 3. below.
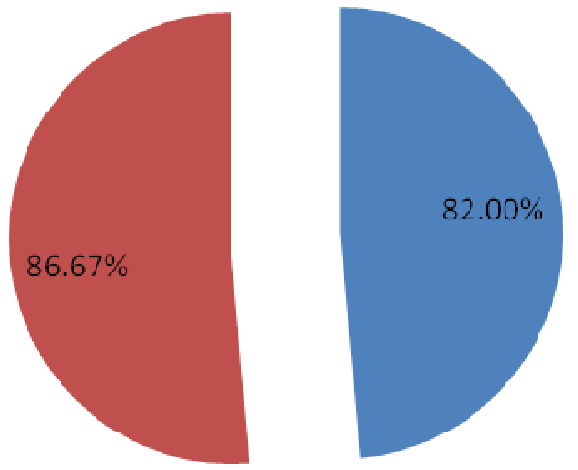

Fig. 3. Transformational leadership and organizational culture through job satisfaction and performance indicators

From Fig. 3. above, the percentage of job satisfaction is $80.00 \%$ and performance is $86.67 \%$.

Therefore, from the results obtained, it can be said that transformational leadership and organizational culture on indicators of job satisfaction and performance can be said to be good.

\section{Conclusion}

From the results of the discussion above, several conclusions can be drawn, including:

1. The effect of transformational leadership and organizational culture through job satisfaction is $80.00 \%$. This implies that job satisfaction at SMP Negeri 1 Pulau Rakyat Asahan is good.

2. The effect of transformational leadership and organizational culture through performance is $86.67 \%$. This implies that the performance of teachers at SMP Negeri 1 Pulau Rakyat Asahan is good.

\section{Bibliography}

Davis, Keith. Newstrom, John W., 1996. Human Behavior at Work :Organizational Behavior (7thEd.).

Fuad Mas'ud. 2004. Concept and Application Organizational Diagnostic Survey, UNDIP, Semarang.

Griffin, Ricky W., 1980. "Relationships Among Individual, Task Design, and Leader Behavior Variables", Academy of Management Journal, Vol. 23, No. 4, 665-683.

Kartono Kartini, 1998. Leaders and Leadership, PT Raja Grafindo Prersada, Jakarta.

Kohl, et all., 1995. "The Effect of Transformational Leadership on Teacher Attitudes and Student Performance in Singapore", Journal of Organizational Behavior, 16:319-333.

Lapin, Laurence. 1990. Statistics for Modern Business Decisions 5th Edition, Harcourt Brace Jovanovich, Publishers.

Lok \& Crawford. 2004. "The Effect of organizational culture and leadership style on job satisfaction and organizational commitment across-National Comparison”, The Journal of Management Development, Vol. 23, No. 4, 321-337.

Mc Cue, Clifford, et all., 1997. The Relationship Between Job Satisfaction and Performance. Public Productivity and Management Review, Vol 41, No.2, pp 160-191.

Menon, Maria E., 2002. Perceptions of Pre-Service and In-Service Teachers Regarding the Effectiveness of Elementary School Leadership in Cyprus. The International Journal of Educational Management, 16 February, p.91-97.

Muh Su'ud. 2000. Social Perceptions About Leader Credibility, Synergy of Business and Management Studies, vol.3, No.1. pp 51-65.

Scarnati, James T., 2002. Leader as Role Models: 12 Rules. Career Development International, 7 Maret, p.181-189. 